\title{
Delignification of Lignocellulosic Biomass Sugarcane Bagasse by Using Ozone as Initial Step to Produce Bioethanol
}

\author{
Hermansyah $^{1 *}$, Hardi Cahyadi ${ }^{1}$, Fatma ${ }^{1}$, Miksusanti ${ }^{1}$, \\ Getari Kasmiarti², Almunady T. Panagan ${ }^{1}$ \\ ${ }^{1}$ Department of Chemistry, Faculty of Mathematics and Natural Sciences, Universitas Sriwijaya, \\ Jalan Raya Palembang Prabumulih KM32, Indralaya 30662, South Sumatra, Indonesia \\ ${ }^{2}$ Study Program of Environmental Science, Graduate Program Universitas Sriwijaya, \\ Jalan Padang Selasa No.524, Bukit Besar, Palembang 30139, South Sumatra, Indonesia
}

Received: 1 December 2020

Accepted: 7 January 2021

\begin{abstract}
The choice of pretreatment is a very important in bioethanol production from lignocellulosic biomass. This helps to eliminate lignin partition between cellulose and hemicellulose. However, various methods generate diverse effects on the material structure and composition. The purpose of this study, therefore, was to delignify sugarcane bagasse by ozonolysis, followed by hydrolysis and fermentation. Also, the morphology of the samples was analyzed using SEM, while hemicellulose, cellulose, and lignin content were characterized by the Chesson process. The sample was hydrolyzed using $1 \%(\mathrm{v} / \mathrm{v})$ sulfuric acid and the bioethanol fermented with Saccharomyces cerevisiae was detected by gas chromatography. Furthermore, ozone was applied for 90 minutes at $\mathrm{pH} 3.0$ in the delignification process. This produces cellulose, hemicellulose, and lignin estimated at 59\%, 22\%, and 6\%, respectively. However, ozonolysis was employed to reduce lignin for up to $217 \%$. Meanwhile, the hydrolysed samples were known to rapidly decrease the reducing sugar from 19.342 to $2.86 \mathrm{mg} / \mathrm{L}$ after heating at $100^{\circ} \mathrm{C}$. Subsequently, the fermentation stage recorded the highest ethanol production, estimated at $0.79 \%(\mathrm{v} / \mathrm{v})$. The result showed lignin removal was conducted in an eco-friendly and efficient condition. Therefore, the need for further study is possible in order to optimize certain parameters for maximum bioethanol production.
\end{abstract}

Keywords: Saccharomyces cerevisiae, ozonolysis, delignification, fermentation, bioethanol

*e-mail: hermansyah@unsri.ac.id 


\section{Introduction}

Bioethanol is a green and renewable energy source as a result of $\mathrm{CO}_{2}$ released during its combustion. This substance does not contribute to the greenhouse effect [1]. Meanwhile, the technologies applied in bioethanol production from lignocellulosic biomass were investigated by assimilated raw material handling, fractional process, good synergy of enzymatic hydrolysis, running steps of simultaneous saccharification (SSF), and yeast strains as fermentation agent known to minimize cost [2]. Furthermore, the sample serves as a significant bioethanol source due to lower cost, renewable, clean, and sustainable energy supply utilized during the conversion process [3]. Sugarcane bagasse is produced as residual/waste material from sugarcane industries, and is abundantly available as bioresource. This lignocellulosic biomass is employed as an alternative energy, raw material, and renewable energy resource. In addition, sugarcane provides an essential food source and energy supply for human needs. Therefore, the material is known to possess the highest bioconversion efficiency of photosynthesis with potential to recover approximately 55 tons of dry matter per hectare of land annually [4]. Thousand tons of sugarcane bagasse are produced as waste every year by sugar industries worldwide. The bagasse contains 33-36\% cellulose, 28-30\% hemicellulose, and $22 \%$ lignin [5]. These compounds exhibits a great possibility to produce fuels, chemicals, and other value added materials, and have been applied as conventional energy, animal feeding, and raw material for paper or board making over a long period of time $[6,7]$.

Furthermore, the second era of bioethanol production approved sugarcane bagasse as an attractive raw source, apart from other lignocellulosic biomass materials. The conversion primarily involves pretreatment, hydrolysis, and fermentation processes $[8,9]$ where the pretreatment or delignification appears as the most crucial to influence the effectiveness of the bioconversion. In addition, the pretreatment was conducted to access cellulose by disrupting the lignocellulosic biomass recalcitrant structures. This is expected to improve the sugar yield concentration employed in the fermentation process. Various pretreatment methods were established, including dilute acid approach, organic solvent, high temperature, liquid water, dissolved ammonia or ozonolysis [10]. This study, therefore applies pretreatment on sugarcane bagasse sample in order to remove the lignin content using ozone.

Ozonolysis is a potentially viable approach in pretreating lignocellulosic biomass known to enhance fermentable sugars. The process deconstructs the lignin and provides the cellulose with easy accessibility to enzymatic digestion [11], although the lignin tend to degrade, but loses negligible cellulose and hemicellulose
[12]. This pretreatment involves a chemical reaction by adding oxidants in the form of ozone, assumed to be efficient in delignification and does not produce side products [13]. The reaction mechanism for ozonolysis is based on ozone attack on the double bonds existing between carbons [14]. Furthermore, the objective of ozonification is to observe the effects of dissolved lignin in enzymatic saccharification [15]. Lignin removal process is expected to increase the hydrolysis yield. The normal pressure and room temperature conditions in the initial treatment do not create the possibility of inhibitor compound formation known to inhibit the fermenting process. Straw is one instance of agricultural waste applying ozonolysis in order to improve cellulose and hemicellulose yields [16]. The moisture content of lignocellulosic materials influences the maximum rate of their reaction with ozone [17]. In ozonolysis pretreatment, there are five most important variables, including $\mathrm{pH}$, consistency, time, temperature, and ozone concentration [18]. Oxygen flow and sample size are also considered as key factors, and are highlighted as the highest influence parameters in statistical analysis [19]. Moreover, gaining an effective and feasible pretreatment could happen in ozonolysis with high sugar release without further delignification [20]. In addition, bioethanol production requires several stages, as the transformation of lignocellulose biomass resources involves raw material pretreatment and hydrolysis. The next stage includes fermentation, and is performed using micro-organisms to convert the sample to bioethanol [21].

\section{Material and Methods}

\section{Materials}

This section provides information on raw material sources, including the chemical composition of the fermentation media, equipment, and precise steps for bioethanol production.

Sugarcane bagasse sample was acquired from a traditional market in Indralaya, Ogan Ilir District, South Sumatera, Indonesia. Various concentrations of sulfuric acid $\left(\mathrm{H}_{2} \mathrm{SO}_{4}\right)$, sodium hydroxide $(\mathrm{NaOH}), \mathrm{HCl}$ (hydrochloric acid), 3,5-dinitrosalicilic acid (DNS), and $\mathrm{K}-\mathrm{Na}$ Tartrate were used. Also, the YPD media consist of $1.0 \mathrm{~g}$ yeast extract, $2.0 \mathrm{~g}$ dextrose, and $2.0 \mathrm{~g}$ pepton, as well as fermentation media comprising $0.4 \mathrm{~g} / \mathrm{L}$ yeast extract, $0.2 \mathrm{~g} / \mathrm{L}\left(\mathrm{NH}_{4}\right)_{3} \mathrm{PO}_{4}, 0.01 \mathrm{~g} / \mathrm{L} \quad \mathrm{MgSO}_{4} .7 \mathrm{H}_{2} \mathrm{O}$, and distilled water. Equipment used include HPLC "Shimadzu DGU-20A5R", gas choromatography "GC2010 plus Shimadzu", autosampler "AOC-20i”, ozonizer, spectrophotometer "UV-Vis BK-D560", scanning electron microscope "(SEM) JEOL JSM 6510 LA". Strain yeast $S$. cerevisiae "ATCC 9763" was involved in the fermentation. 


\section{Preparation of Sugarcane Bagasse}

The fresh sugarcane bagasse was separated and cleaned to remove impurities, and then cut into smaller pieces, followed by drying. The sample was then grinded and filtered using 40 mesh to obtain powdered sugarcane bagasse.

\section{Delignification of Sugarcane Bagasse with Ozone}

Sugarcane $(4.0 \mathrm{~g})$ powder was soaked in $280 \mathrm{~mL}$ distilled water using a $500 \mathrm{~mL}$ erlenmeyer flask. Subsequently, the ozone delignification was conducted at $\mathrm{pH} 3.0$ and without $\mathrm{pH}$ adjustment. The sugarcane solution was passed through the ozone gas at a flow rate of $50 \mathrm{~g} / \mathrm{min}$ proceeded successively for $10,20,30,40$, 50, 60, 70, 80, and 90 mins.

\section{Hemicelluloses, Lignin, and Cellulose Determination}

Hemicellulose, cellulose, and lignin were determined by the Chesson method (Datta et al., 1981) as follows: weight A consisting of $1.0 \mathrm{~g}$ dry sample was added into $150 \mathrm{~mL} \mathrm{H} \mathrm{H}_{2} \mathrm{O}$ refluxed at $100^{\circ} \mathrm{C}$ for 2 hours. The residue was filtered, and dried to achieve constant weight (B). This was then added into $150 \mathrm{~mL}$ of $0.5 \mathrm{M}$ $\mathrm{H}_{2} \mathrm{SO}_{4}$, and refluxed for 2 hours at $100^{\circ} \mathrm{C}$. However, the result was filtered, and its residue was dried to constant weight (C). Dry residue soaked with $10 \mathrm{~mL}$ of $72 \% \mathrm{H}_{2} \mathrm{SO}_{4}$ at room temperature for 4 hours continuously placed $150 \mathrm{~mL}$ of $0.5 \mathrm{M} \mathrm{H}_{2} \mathrm{SO}_{4}$ and was refluxed at $100^{\circ} \mathrm{C}$ for 2 hours. The product was washed and filtered to neutral $(400 \mathrm{~mL})$ using $\mathrm{H}_{2} \mathrm{O}$. This was then dried, weighed (D), and heated at $300^{\circ} \mathrm{C}$ for 45 minute in a furnace to achieve constant weight (E). Furthermore, the morphology of pretreated samples was investigated using SEM placed on graphite at $45^{\circ} \mathrm{C}$ inclination.

\section{Hydrolysis of Delignified Sugarcane Bagasse}

Delignified sugarcane bagasse (4.0 g) was hydrolyzed using $20 \mathrm{~mL}$ of $0 \%, 1 \%, 2 \%, 3 \%(\mathrm{v} / \mathrm{v})$ sulfuric acid, and $280 \mathrm{~mL}$ distilled water. These processes were performed respectively for $15 \mathrm{~min}$ at $100^{\circ} \mathrm{C}$ and at room temperatures.

\section{Determination of Reduced Sugar Content by DNS Method and HPLC}

Hydrolyzed sample solution $(1 \mathrm{~mL})$ was poured into a test tube, followed by the addition of $1 \mathrm{~mL}$ DNS reagent. This was then heated to $100^{\circ} \mathrm{C}$ for 5 minutes in a water bath and subsequently cooled at room temperature for 5 minutes. Subsequently, the sample was measured with UV-Vis spectrophotometer at $540 \mathrm{~nm}$ wavelength $(\lambda)$, and further analyzed using HPLC with conditions, including the column C18, flowing rate at $1 \mathrm{~mL} / \mathrm{min}$, uv-vis detector $254 \mathrm{~nm}$, pressure $220 \mathrm{kgf} / \mathrm{cm}^{2}$ and solvent composition of acetonitrile: aquabidest (60:40).

\section{Bioethanol Fermentation}

Yeast S.cerevisiae ATCC 9763 cells were cultivated on YPD medium overnight at $30^{\circ} \mathrm{C}$ with a stirring of $100 \mathrm{rpm}$. A $5 \mathrm{ml}$ inoculum were transferred into $50 \mathrm{~mL}$ fermentation media containing $2.0 \mathrm{~g} / \mathrm{L}$ yeast extract, $1.0 \mathrm{~g} / \mathrm{L} \quad\left(\mathrm{NH}_{4}\right)_{3} \mathrm{PO}_{4}, \quad 0.05 \mathrm{~g} / \mathrm{L} \quad \mathrm{MgSO}_{4} .7 \mathrm{H}_{2} \mathrm{O}, \quad 200 \mathrm{~mL}$ distilled water, and $25 \mathrm{ml}$ hydrolysate. These were incubated at $30^{\circ} \mathrm{C}$ with stirring of $100 \mathrm{rpm}$. Gas chromatography was introduced to detect ethanol at the following conditions, termed column length $30 \mathrm{~m}$, pressure $42.8 \mathrm{kPa}$, specified temperature $50-260^{\circ} \mathrm{C}$ for 25 mins, temperature of FID detector temperature $300^{\circ} \mathrm{C}$, and helium flow rate as carrier gas $30 \mathrm{~mL} / \mathrm{min}$.

\section{Results and Discusssion}

\author{
Lignin, Cellulose, and Hemicelluloses \\ Determination of Sugarcane Bagasse \\ with Ozone
}

The lignin, cellulose, and hemicellulose were determined by Chesson method with $\mathrm{pH} 3.0$ and without $\mathrm{pH}$. Table 1 shows the results of the percentage cellulose, lignin, and hemicellulose. Lignin content decreased consistently from $10-80 \mathrm{~min}$ contact time between sugarcane bagasse and ozone at $\mathrm{pH} 3.0$ as well as without $\mathrm{pH}$ adjustment condition. This decline instigates the rise in cellulose and hemicellulose percentages with $\mathrm{pH} 3$ showing higher composition compared without $\mathrm{pH}$ adjustment.

The sample was dried, mashed with grinder, filtered using $40 \mathrm{mesh}$, and then soaked in distilled water. Reducing the cellulose polymerization degree and increasing the particular surface area tend to modify smaller size particles. Sample solution was flowed by ozone generated from $0,10,20,30,40,50,60,70,80$, and $90 \mathrm{~min}$ at $\mathrm{pH} 3.0$ and without $\mathrm{pH}$. Based on Table 1, the initial biomass sample before pretreatment contained $19 \%$ lignin, 40\% cellulose, and 9\% hemicellulose. The results after ozone pretreatment for 10 min with $\mathrm{pH}$ 3.0, showed the sample composed of $19 \%$ lignin, $40 \%$ cellulose, and 9\% hemicellulose, while without $\mathrm{pH}$, the values were $17 \%$ lignin, $42 \%$ cellulose, and $10 \%$ hemicellulose. These conclusions assumed $10 \mathrm{~min}$ pretreatment was not enough to significantly modify the three main compounds, termed lignin, cellulose, and hemicellulose.

The samples were reported to contain 10\% lignin, $51 \%$ cellulose, and $18 \%$ hemicellulose at $\mathrm{pH} 3.0$, while without $\mathrm{pH}$, the values were $12 \%$ lignin, $47 \%$ cellulose, and $13 \%$ hemicellulose after 50 min pretreatment. This result indicated the contact reaction between the bagasse and ozone, within this period, reduces the lignin and observed the cellulose and hemicellulose 
Table 1. Lignin, cellulose, and hemicellulose content after pretreatment using ozone analyzed using Chesson method.

\begin{tabular}{|c|c|c|c|c|c|c|}
\hline \multirow{2}{*}{ Time (min) } & \multicolumn{3}{|c|}{ Without pH adjustment } & \multicolumn{3}{c|}{$\mathrm{pH} 3$} \\
\cline { 2 - 7 } & \% Lignin & \% Cellulose & \% Hemicellulose & \% Lignin & \% Cellulose & \% Hemicellulose \\
\hline 0 & 19 & 40 & 9 & 19 & 40 & 9 \\
\hline 10 & 17 & 42 & 10 & 19 & 39 & 11 \\
\hline 20 & 17 & 42 & 10 & 16 & 43 & 12 \\
\hline 30 & 15 & 43 & 11 & 15 & 45 & 15 \\
\hline 40 & 12 & 45 & 12 & 10 & 51 & 17 \\
\hline 50 & 12 & 47 & 13 & 10 & 53 & 18 \\
\hline 60 & 10 & 48 & 15 & 9 & 56 & 19 \\
\hline 70 & 9 & 49 & 17 & 6 & 58 & 23 \\
\hline 80 & 8 & 51 & 20 & 6 & 59 & 22 \\
\hline 90 & 8 & 52 & 20 & & 51 \\
\hline
\end{tabular}

to gradually increase. Moreover, after $80 \mathrm{~min}$ with $\mathrm{pH} 3.0$, the sample reported $6 \%$ lignin, 58\% cellulose, and $23 \%$ hemicellulose, while without $\mathrm{pH}$ estimated $8 \%$ lignin, 51\% cellulose, and 20\% hemicellulose. In addition, the percentage lignin reduction for $80 \mathrm{~min}$ at $\mathrm{pH} 3.0$ and without $\mathrm{pH}$ corresponded to $68.4 \%$ and $57.9 \%$, respectively. This decrease is due to the lignin content undergoing oxidation reactions to form alcohol compounds of Kumaril, coniferil, and synaphyl [13]. Conjugated double bond present in chemical compounds are known to actively react with ozone, and are regarded as the structure of lignin functional groups with high electron density. This ozone pretreatment tends to degrade the ether bond between lignin units and $\beta-O$ 4 , concentrate the $\beta-\beta$ and $\beta-5$ carbon-carbon bonds, reduce the percentage of guaiacyl, syringyl, hydroxyl and methoxyl present in an effort to terminate the stable cross-linking between ferulic acid and lignin [22].

Several oxidative pretreatments using $\mathrm{H}_{2} \mathrm{O}_{2}$ as common oxidizing agent are expected to remove $50 \%$ lignin with the capacity to produce potential hemicellulose yield in $1-2 \%$ hydrogen peroxide at $25-30^{\circ} \mathrm{C}$ [23]. An effective lignocellulose pretreatment possibly improves certain conditions, including surface area accessibility, cellulose decrystallization, hemicellulose and cellulose partial depolymerization, as well as dissolves lignin and hemicellulose. Pretreatment shows the possibility to modify the lignin structure in order to increase the material enzymatic digestibility. In addition, the conditions reduce the sugars and also manages cost [24]. Cellulose and hemicellulose content, after pretreatment using $50 \%$ ethanol, resulted to a composition of $52.24 \%$ and $11.48 \%$, respectively [25].

The data after ozone delignification for $80 \mathrm{~min}$ at the $\mathrm{pH} 3.0$, represents the increase in cellulose and hemicellulose by $45 \%$ and $155 \%$, respectively, while without $\mathrm{pH}$ estimates $27.5 \%$ and $122 \%$, correspondingly. These results highly altered all lignin, cellulose, and hemicellulose compared to previous work by using $\mathrm{NaOH} 2 \mathrm{~N}$ for $40 \mathrm{~min}$, where cellulose was improved by $26.8 \%$ and lignin declined by $43.3 \%$ [26]. Therefore, the effects of the reaction were observed as longer contact time, fast lignin degradation, and enhanced cellulose and hemicellulose content. However, at $90 \mathrm{~min}$ pretreatment, lignin ceased to decline despite longer contact time. The degradation was stronger at $\mathrm{pH} 3.0$ compared to without $\mathrm{pH}$. Delignification using ozone for $80 \mathrm{~min}$ at $\mathrm{pH} 3.0$ generated $6 \%$ lignin content, while at $\mathrm{pH}$ adjustment produced $8 \%$. The products then decreased temporarily or were similar to the $80 \mathrm{~min}$ pretreatment. Meanwhile, cellulose and hemicellulose were slightly modified. Various cellulose phases were discovered subsequently, including solid and liquid [26]. Based on the ozone data, the $80 \mathrm{~min}$ specification was evaluated as an efficient time needed to reduce the lignin. Furthermore, the delignified sugarcane bagasse showed lower lignin, and was removed efficiency from the samples. Ozonolysis pretreatment effectively delignified the sample as no toxic residue or low energy was applied. This was attributed to standard pressure and room temperature [24].

\section{Morphology of Pretreated Samples}

Lignin removal resulted to morphology modifications and was confirmed by SEM data images. Focus observation showed the contact time was considered as the parameter with the strongest impact. Fig. 1 represents the SEM characterization results at 1,000x magnification. The samples were categorized as A (pretreated), B (pretreated at $\mathrm{pH} 3$ ) and $\mathrm{C}$ (pretreated at without $\mathrm{pH}$ ). Fig. 1 also shows the morphological sample variation due to structural degradation, particularly lignin.

Fig. 1a) reveals the surface of the sugarcane bagasse before pretreating using ozone was not defective, but 
smooth and amorphous. This phenomenon described the component of lignin, cellulose, hemicellulose known to have contributed to its morphology. Figs 1 b) and c) depicts the samples after pretreatment using ozone for 20,40,60,60, and $80 \mathrm{~min}$ at $\mathrm{pH} 3.0$ and without $\mathrm{pH}$, respectively. The surface clearly appeared different compared to untreated. Samples of Champaca timber (Elmerrilliaovalis) pretreated using microwave $3000 \mathrm{~W}$ for $40 \mathrm{~min}$, also resulted to tremendous damage as several components were shattered and exposed [27]. Furthermore, the earlier data indicates the structural lignocellulose probably changes due to the degradation of lignin macromolecules.

The lowest lignin content was then hydrolyzed using acid. Saccharification or hydrolysis of pretreated sugarcane bagasse consisting of cellulose and hemicellulose tend to generate monosaccharide sugar. The hydrolysis of crystalline cellulose was conducted at a temperature of $200-240^{\circ} \mathrm{C}$ using $1.5 \%$ acid concentration [21]. This promoted the degradation of glucose into hydroxyl, methyl, furfural and other undesired products. To avoid these by-products, this study was conducted by hydrolysis using $0,1.0,2.0$, and $3.0 \%$ sulfuric acids under room temperature and applied heat at $100^{\circ} \mathrm{C}$. This is known to degrade cellulose into glucose. The use of dilute acid shows several advantages, including the absence of special equipment, minimizing the danger of acid, and no acid recovery [28].

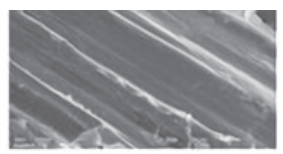

a)

$20 \min$
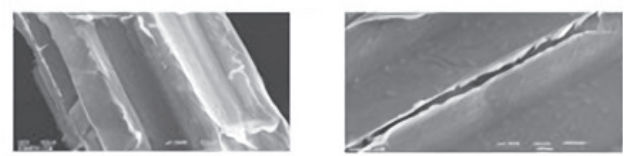

$40 \mathrm{~min}$
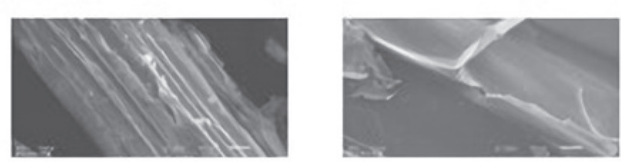

$60 \mathrm{~min}$
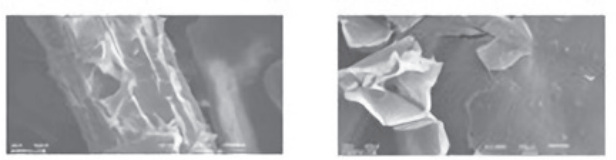

$80 \min$

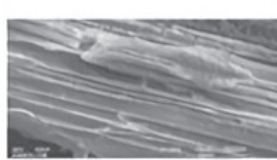

b)

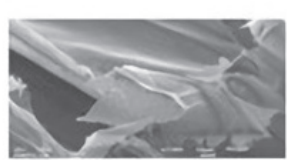

c)
Fig. 1. Morphological Structure of sugarcane bagasse samples a) Samples before pretreatment. b) Pretreated samples at $\mathrm{pH}$ 3.0 for 20, 40, 60, 80 min. c) Pretreated samples at without $\mathrm{pH}$ adjusment for $20,40,60,80 \mathrm{~min}$.

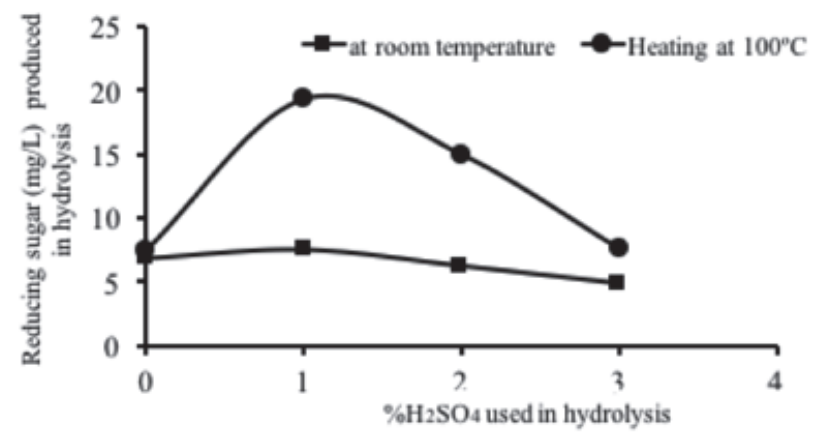

Fig. 2. Reducing sugar produced from acid hydrolysis.

\section{The Reduced Sugar Content by DNS Method and HPLC}

DNS method was applied to determine the amount of the reducing sugar. The decline is due to the presence of carbonyl groups which can be oxidized to oxidizing carboxyl groups (DNS). The DNS solution, initial yellow in color, was reduced to 3-amino-5-nitrosalicylic acid to form brownish-red coloration known to be measured using a UV-Vis spectrophotometer. This reaction between sugar and DNS occurred in the presence of alkaline. Fig. 2 showed the concentration of the reducing sugar was produced from hydrolysis sugarcane bagasse. This data, however, indicated the highest sample content was specified as the sugar produced from hydrolysis using $1 \% \mathrm{H}_{2} \mathrm{SO}_{4}$ at $100^{\circ} \mathrm{C}$.

a)
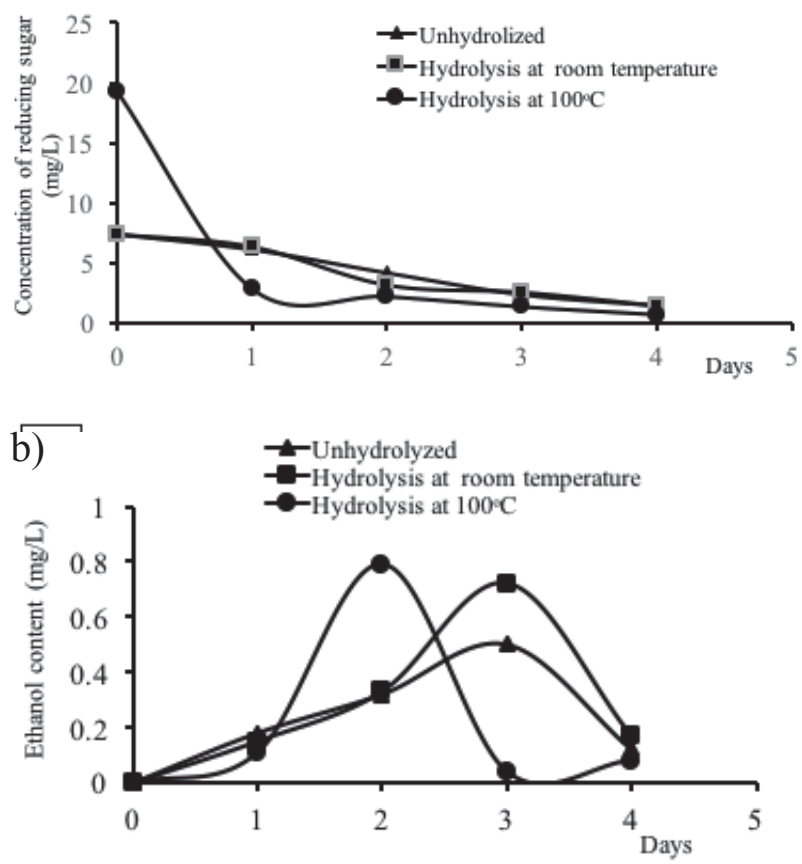

Fig 3. a) Concentration of reducing sugar during fermentation; b) Percentage of ethanol produced during fermentation on the $1^{\text {st }}, 2^{\text {nd }}, 3^{\text {th }}$, and $4^{\text {th }}$ day. 
In this hydrolysis, unhydrolyzed sample, glucose, fructose, and sucrose were $4.55,2.95$, and $2.46 \mathrm{mg} / \mathrm{L}$ respectively. The hydrolysis of the pretreated bagasse at room temperature resulted to glucose, fructose, and sucrose with composition of 13.91, 9.7, and $33.48 \mathrm{mg} / \mathrm{L}$, respectively. Subsequently, the sample at $100^{\circ} \mathrm{C}$ resulting to glucose and sucrose were 19.87 and $33.48 \mathrm{mg} / \mathrm{L}$, respectively, although fructose was not detected. This data showed the sample is a potential material for bioethanol production by fermentation despite having low concentration. Pretreated bagasse after lignin and hemicellulose removal hydrolyzed by $2 \%$ sulfuric acid, not only generated $22.74 \mathrm{~g} / \mathrm{L}$ of fermentable sugar, but also inhibitory compounds [29]. However, hydrolysis conducted at $160^{\circ} \mathrm{C}$ using dilute sulfuric has been widely applied in various industries [30].

\section{Fermentation}

The fermentation process commenced after the hydrolysis of pretreated sugarcane bagasse using ozone. By using separately hydrolysis and fermentation (SHF) method, pretreated substrate was employed with S.cerevisiae ATCC 9763 to produce bioethanol. Fig. 3. highlights ethanol and reducing sugar were measured during fermentation in the $1^{\text {st }}, 2^{\text {nd }}, 3^{\text {rd }}$, and $4^{\text {th }}$ stages. The sugar concentration decreased during fermentation, but increased for produced ethanol. However, the hydrolysis treatment at $100^{\circ} \mathrm{C}$ rapidly decreased the sugar content from $19.342 \mathrm{mg} / \mathrm{L}$ to $2.86 \mathrm{mg} / \mathrm{L}$. Furthermore, the fermentation process significantly produced the highest ethanol, estimated at $0.79 \%(\mathrm{v} / \mathrm{v})$.

The ethanol showed lower concentrations, although lignin was removed. This emphasizes on the need to optimize various parameters, including incubation temperature, $\mathrm{pH}$, fermentation media and time, microbial agent, etc. The application of SHF method tend to lose certain concentrations of the sugar, while the substrate transfers from hydrolysis to fermentation vessel. Abo-state produced ethanol using SHF with enzymatic hydrolysis Trichoderma viride and Candida tropicalis resulting to $226 \mathrm{~kg}$ (convert to \%) ethanol per ton bagasse, while Aspergillus terreus for hydrolysis and S.cerevisiae for fermentation produced $185 \mathrm{~kg}$ per ton bagasse (convert to \%) [31]. By using simultaneous saccharification and fermentation (SSF), it produced better results, the fermentation performed at $30^{\circ} \mathrm{C}$ for 96 hour in the presence of ammonium nitrate generated $5.90 \%$ yield [32]. However, saccharification step is conducted by commercial cellulose enzyme known to be expensive.

\section{Conclusions}

Based on results and discussion, the delignification of sugarcane bagasse to produce bioethanol shows ozonolysis as an efficient process in lignin removal.
By ozonolysis method lignin contents were reduced from initial content $19 \%$ became $6 \%$ and $8 \%$ at $\mathrm{pH} 3$ and without $\mathrm{pH}$ preteratments, respectively. Furthermore, lignin removal is followed by the optimization of hydrolysis and fermentation processes, otherwise bioethanol production is not obtained maximally. In this works, the best performance was hydrolysis treatment at $100^{\circ} \mathrm{C}$ which decreased the sugar content from $19.342 \mathrm{mg} / \mathrm{L}$ to $2.86 \mathrm{mg} / \mathrm{L}$, and the fermentation process produced $0.79 \%(\mathrm{v} / \mathrm{v})$ ethanol.

\section{Acknowledgements}

The research/publication of this article was funded by DIPA of Public Service of Universitas Sriwijaya 2020. SP DIPA-023.17.2.677515/ 2020, revision 01, on March 16, 2020. In accordance with the Rector's Decree Number : 0685/UN9/SK.BUK.KP/2020, on July $15,2020$.

\section{Conflict of Interest}

The authors declare no conflict of interest.

\section{References}

1. ABO O.B., GAO M., WANG Y., WU C., MA, H., WANG Q. Lignocellulosic biomass for bioethanol : an overview on pretreatment, hydrolysis and fermentation processes. Ren Env. Health, 34 (1), 1, 2019.

2. CHEN H, and FU X. Industrial technologies for bioethanol production from lignocellulosic biomass. Renewable and Sustainable Energy Reviews, 57, 468, 2016.

3. BAIG K.S., WU J., TURCOTTE G., DOAN H.D. Novel ozonation technique to delignify wheat straw for biofuel production. Energy and Environment, 26 (3), 303, 2015.

4. SIDANA A., FAROOQ U. Sugarcane Bagasse: A Potential Medium for Fungal Cultures. Chinese Journal of Biology, 2014, 1, 2014.

5. BETANCUR G.J.V., PEREIRA N. Sugar cane bagasse as feedstock for second generation ethanol production. Part I: Diluted acid pretreatment optimization. Electronic Journal of Biotechnology, 13 (3), 1, 2010.

6. ZANIN G.M., SANTANA C.C., BON E.P.S., GIORDANO R.C.L., DE MOARES F.F., ANDRIETTA S.R., NETO C.C.D.C., MACEDO I.C., FO D.L., RAMOS L.P., FONTANA J.D. Brazilian Bioethanol Program. Applied Biochemistry Biotechnol, 84, 1147, 2000.

7. WYMAN C.E., DALE B.E, ELANDER R.T., HOLTZAPPLE M, LADISCH M.R., LEE Y.Y. Coordinated development of leading biomass pretreatment technologies. Bioresource Technology, 96, 1959, 2005.

8. FATMA S., HAMEED A., NOMAN M., AHMED T., SHAHID M., TARIQ M., SOHAIL I., TABASSUM R. Lignocellulosic Biomass: a sustainable bioenergy source for future. Protein Pept. Lett, 25, 1, 2018.

9. BRETHAUER S., STUDER M.H. Biochemical Conversion Processes of Lignocellulosic Biomass to 
Fuels and Chemicals - A Review. CHIMA, 69 (10), 572, 2015.

10. XU Z., HUANG F. Pretreatment Methods for Bioethanol Production. Appl. Biochem. Biotechnol, 174, 43, 2014

11. BHATTARAI S., BOTTENUS D., IVORY C.F., GAO A.H., BULE M., PEREZ M.G., CHEN S. Simulation of the ozone pretreatment of wheat straw. Bioresource Technology, 196, 78, 2015.

12. ANDERSEN S.L.F., CASTOLDI R., GARCIA J.A.A., BRACHT A., PERALTA R.A., DE LIMA E.A., HELM C.V., MOREIRA R.D.F.P.M., PERALTA R.M. Improving enzymatic saccharification of Eucalyptus grandis branches by ozone pretreatment. Wood Science Technology, 53 (1), 49, 2019.

13. TALEBNIA F. Ethanol Production from Cellulosic Biomass by Encapsulated Saccharomyces cerevisiae. PhDThesis. Chalmers University of Technology, Goteborg, Sweden. 2008.

14. MULAKHUDAIR A.R., HANOTU J, ZIMMERMAN W. Exploiting ozonolysis-microbe synergy for biomass processing: Application in lignocellulosic biomass pretreatment. Biomass and Bioenergy, 105, 147, 2017.

15. MARTINEZ I.B., GUZMAN N., PENA E., VAZQUEZ T., CAMACHO R.C., FOLCH J., SALAZAR J.A.H., ABURTO J. Ozonolysis of alkaline lignin and sugarcane bagasse: Structural changes and their effect on saccharification. Biomass and Bioenergy, 94, 167, 2016.

16. ALVIRA P, TOMAS-PEJO E., BALLESTEROS M., NEGRO M.J. Pretreatment technologies for an efficient bioethanol production process based on enzymatic hydrolysis: A review. Bioresource Technology, 101 (13), 4851, 2010.

17. BEN E.M., MANISOVA O.R., LUNIN V.V. Effect of Moisture Content on the Interaction between Lignocellulosic Materials and Ozone. Russian Journal of Physical Chemistry, 91 (7), 1190, 2017.

18. TRIPATHI S.K., BHARDWAJ N.K., GHATAK H.R. Determination of main parameters affecting Ozone bleaching of wheat straw pulp using plackett - burman design determination of Mmain parameters affecting ozone bleaching of wheat straw. Ozone Science English, 40 (2), 1, 2017.

19. TRAVAINI R, MARTIN-JUAREZ J, LORENZOHERNANDO A., BOLADO-RODRIGUEZ S. Ozonolysis: An advantageous pretreatment for lignocellulosic biomass revisited. Bioresource Technology, 199, 2, 2015.

20. ROSEN Y., MAMANE H., GERCHMAN Y. Short Ozonation of Lignocellulosic Waste as Energetically Favorable Pretreatment. BioEnergy Res, 12 (2), 292, 2019.

21. CARDONA C.A., QUINTERO J.A., PAZ I.C. Production of bioethanol from sugarcane bagasse: Status and perspectives. Bioresource Technology, 101 (13), 4754, 2010.

22. FANG S., WANG W., TONG S., ZHANG C., LIU P. Evaluation of the effects of isolated lignin on cellulose enzymatic hydrolysis of corn stover pretreatment by $\mathrm{NaOH}$ combined with ozone. molecules, 23 (1495), 1, 2018.

23. CHATURVEDI V., VERMA P. An overview of key pretreatment processes employed for bioconversion of lignocellulosic biomass into biofuels and value added products. 3 Biotech, 3, 415, 2013.

24. MAURYA P.D., SINGLA A., NEGI S. An overview of key pretreatment processes for biological conversion of lignocellulosic biomass to bioethanol. 3 Biotech, 5 (5), 597, 2015.

25. WIDJAJA T., ALTWAYA., NURKHAMIDAH S., EDAHWATI L., LINI F.Z., OKTAFIA F. The effect of pretreatment and variety of microorganisms to the production of ethanol from coffee pulp. ARPN Journal Engineering and Applied Science., 11 (2), 1056, 2016.

26. MARYANA R., MA'RIFATUN D., WHENI A.I., SATRIYO K.W., RIZAL W.A. Alkaline Pretreatment on Sugarcane Bagasse for Bioethanol Production. Energy Procedia, 47, 250, 2014.

27. SANGIAN H.F., PANGAU R.J., TAMUNTUAN H.G., ZULNAZRI Z. The structural analysis of the lignocellulose, Champaca timber (Elmerrilliaovalis) modified by the microwave the structural analysis of the lignocellulose. Chemistry Engineering Transactions, 65, 229, 2018.

28. OSVALDO Z., PANCA P., FAIZAL M. Pengaruh Konsentrasi Asam dan Waktu Pada Proses Hidrolisis dan Fermentasi Pembuatan Bioetanol dari Alang-alang. Jurnal Teknik Kimia, 18 (2), 52, 2012.

29. DUSSAN K.J., SILVA D.D.V., MORAES E.J.C., ARRUDA P.V., FELIPE M.G.A. Dilute-acid hydrolysis of cellulose to glucose from sugarcane bagasse. Chemistry Engineering Transactions, 38, 433, 2014.

30. HAMELINCK N.C., VAN HOOIJDONK G., FAAIJ P.A. Ethanol from lignocellulosic biomass: techno-economic performance in short-, middle- and long-term. Biomass and Bioenergy, 28, 384, 2005.

31. ABO-STATE M.A., RAGAB A.M.E, EL-GENDY N.S., FARAHAT L.A., Madian HR. Effect of different pretreatments on Egyptian sugar-cane bagasse saccharification and bioethanol production. Egyptian Journal of Petroleum, 22 (1), 161, 2013.

32. NADEEM M., AFTAB M.U., IRFAN M., MUSHTAQ M., QADIR A., SYED Q. Production of ethanol from alkali-pretreated sugarcane bagasse under the influence of different process parameters. Frontier Life Science, 8 (4), 37, 2015. 
